\title{
CONGENITAL HEART BLOCK
}

\author{
BY \\ MAURICE CAMPBELL AND M. G. THORNE \\ From the Cardiac Department, Guy's Hospital, and the Institute of Cardiology \\ Received April 10, 1955
}

Accurate prognosis of any condition demands a knowledge of its natural history, and often this is less complete than we would wish. This is true of several congenital abnormalities of the heart and the present paper is a contribution to the natural history of congenital heart block.

In 1934 Campbell and Suzman reported 8 patients with congenital complete heart block: two of these, both with other cardiac abnormalities, died. The subsequent progress of the other six and of a seventh patient was reported by Campbell in 1943, when their ages were between 22 and 43 years.

It seems worth reporting the condition of these seven patients (referred to as Group I) after another ten years, and we have succeeded in seeing all of them except one about whom we have had replies from her and from her doctor. Their progress during these ten years will be described first, and then the cardiac findings at their recent examination. Finally, eight other patients with congenital malformations of the heart as well as heart block will be described (Group II): they have all been seen in the last few years.

\section{The Present Condition of the Seven Patients (Group I)}

One of these seven patients (Case 9) has died with an obscure cardiovascular condition since this paper was first written. The other six are still leading normal lives, with the usual variety of activity. Only one of the three women is married and she has no children. None of them has any significant cardiac symptoms so it is clear that patients can get on well for forty years or more with congenital heart block. Except for one (Case 4) who has had Stokes-Adams attacks-the last, eight years ago - they have had no illnesses that can be directly attributed to their heart block. They have, however, had at least their share of other diseases; one case of tuberculosis with a good recovery (Case 2) and one case of essential hypertension (Case 5) are perhaps no more than might be expected by chance, but two endocrine disorders, diabetes mellitus (Case 3) and myxodema (Case 9), are perhaps more than would be expected.

In 1934 and in 1943 the heart block was complete in all these patients and so far as was known always had been. In 1955 this was still so (Fig. 1) in all except Case 7 who at some unknown date had changed from complete heart block to sinus rhythm with latent heart block (see Fig. 4). The heart was of normal size (Fig. 2) in all except Case 8 and perhaps Case 9. Case 8 was the only one who was thought to have any other cardiac abnormality and none had any evidence of a ventricular septal defect. Some details are given in Table I and for convenience of reference they have been given the same numbers as in the earlier papers.

[Cases 1 and 6. These two are not included in the seven followed-up as they died when five years old, one before and one soon after the paper of Campbell and Suzman (1934): both had other abnormalities of the heart.] 


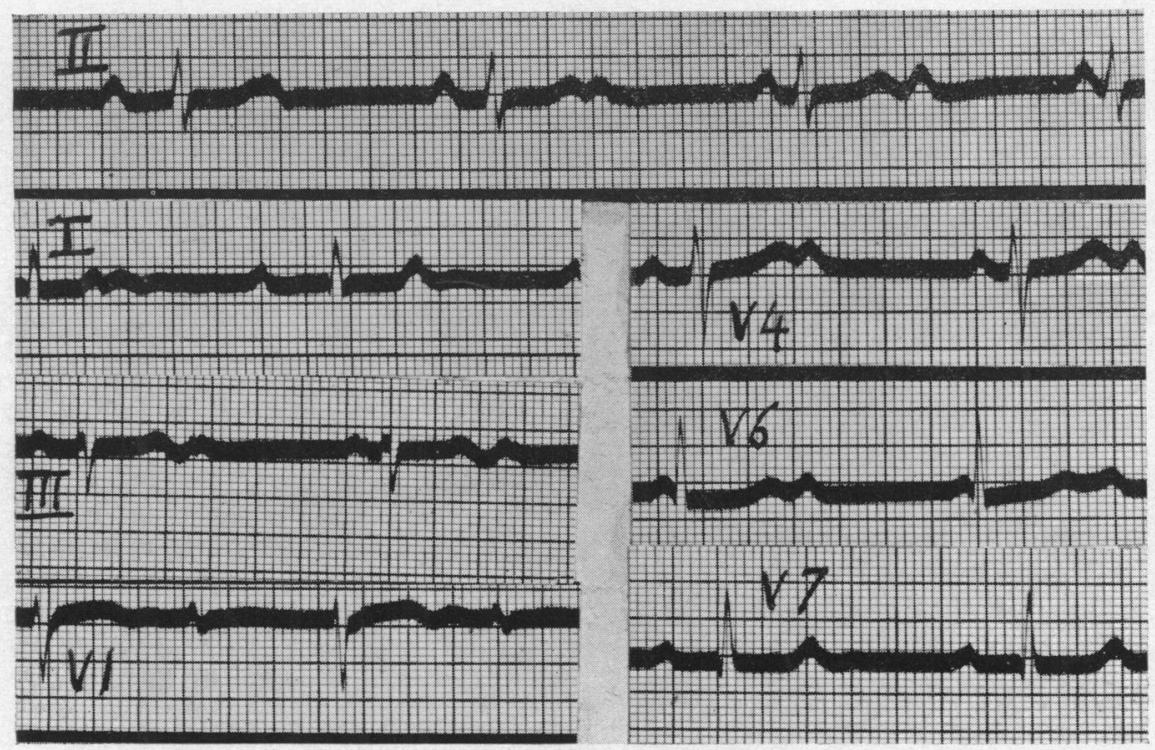

FIG. 1.-A typical electrocardiogram showing no abnormality except the complete heart block. Above, a longer run of lead II to show the heart block is complete. Case 2.

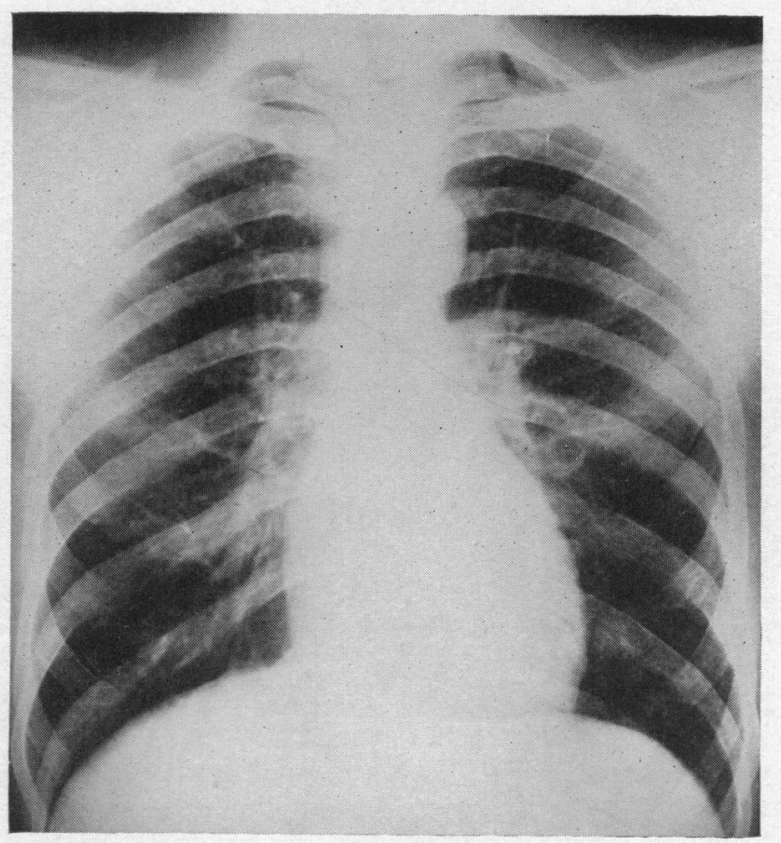

FIG. 2.-A typical small normal heart (c.t.r. $44 \%$ : m.t.d. $12 \cdot 2 / 28 \mathrm{~cm}$.) with rather prominent lung markings but no increased pulsation. This was the picture seen in most of the patients. Case 4. 
Case 2. This woman, now aged 40, looks well and is of good physique. In 1938 she had pulmonary tuberculosis but soon recovered, and the radiograms of the lungs now show some small calcified areas only. She is married and leads a normal life but does not feel able to do as much as she would like, being a little breathless with the heavier housework.

Case 3. This man, now aged 35, served in the R.A.F. during the war, when he was passed for flying duties. He is now working as an electrician. In 1949 he was found to have diabetes mellitus, but with dieting and insulin he keeps fit and leads a normal life.

Case 4. This man, now aged 37 years, has kept extremely well. Although he has cut down his previous activities which were unusually energetic both at work and at play, he leads a normal and full life as a planning engineer. He is the only patient of the series who has experienced StokesAdams attacks but the last occurred eight years ago.

Case 5. This woman, now aged 56, did her housework and worked on a farm for twenty years, walking two miles to her work. She writes that she is still well and complains only of some tightness and wheeziness in the chest, and that she can not now work or dig or cycle as energetically as she used to. She has had no occasion to visit a doctor since we saw her last in 1927 . We have been unable to persuade her to come to London but she has at our request seen her doctor. $\mathrm{He}$ informs us that she is overweight and has to stop sometimes on stairs or hills because of tightness in the chest and dyspnœa and she has some orthopnœa at night. Her heart is large but this is probably due to essential hypertension as her blood pressure which was 190/90 in 1927 is now $260 / 120 \mathrm{~mm}$. Her heart rate was generally between 44 and 50 and is now 54 a minute, so it has not become slower as she has grown older.

Case 7. This woman, now aged 43, worked as a hairdresser when she was young and as an instrument maker during the war. She has given up her employment but says that she is working harder at home and is without symptoms. She is tall and stooping but looks well. To our surprise the heart rate was not the usual slow one, but was 120 a minute. An electrocardiogram showed that instead of complete heart block (Fig. 3) there was a sinus tachycardia with latent heart block,

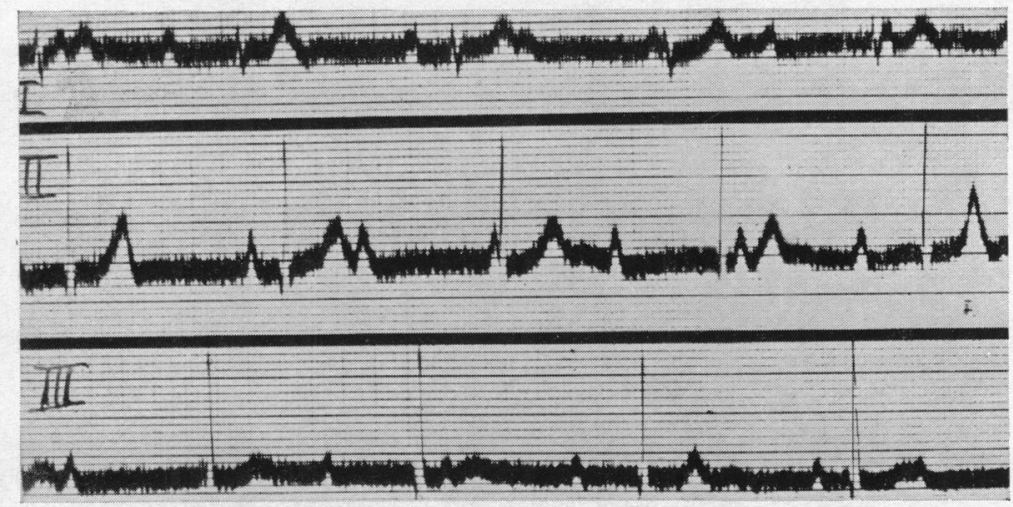

FIG. 3.-Congenital complete heart block. In 1932 the block was complete (A 86, V 46) but in 1954 it was latent (see Fig. 4). Case 7 in 1932.

the $\mathrm{P}-\mathrm{R}$ interval being prolonged up to $0.44 \mathrm{sec}$. (Fig. 4). She was unaware of any difference and could not say when the tachycardia had started or what was now her usual rate, but at three subsequent visits during the next year she was still in sinus rhythm with a long P-R interval, at somewhat slower rates of between 70 and 90 (Fig. 4) and said that when at home it was now generally between 60 and 70 a minute.

Case 8 . This man, now aged 38 , worked exceptionally hard during the war laying concrete floors, and when younger played football for his club team and won several boxing contests. In 1949, in view of his large heart and the presence of left bundle-branch block (Fig. 5), he was advised 


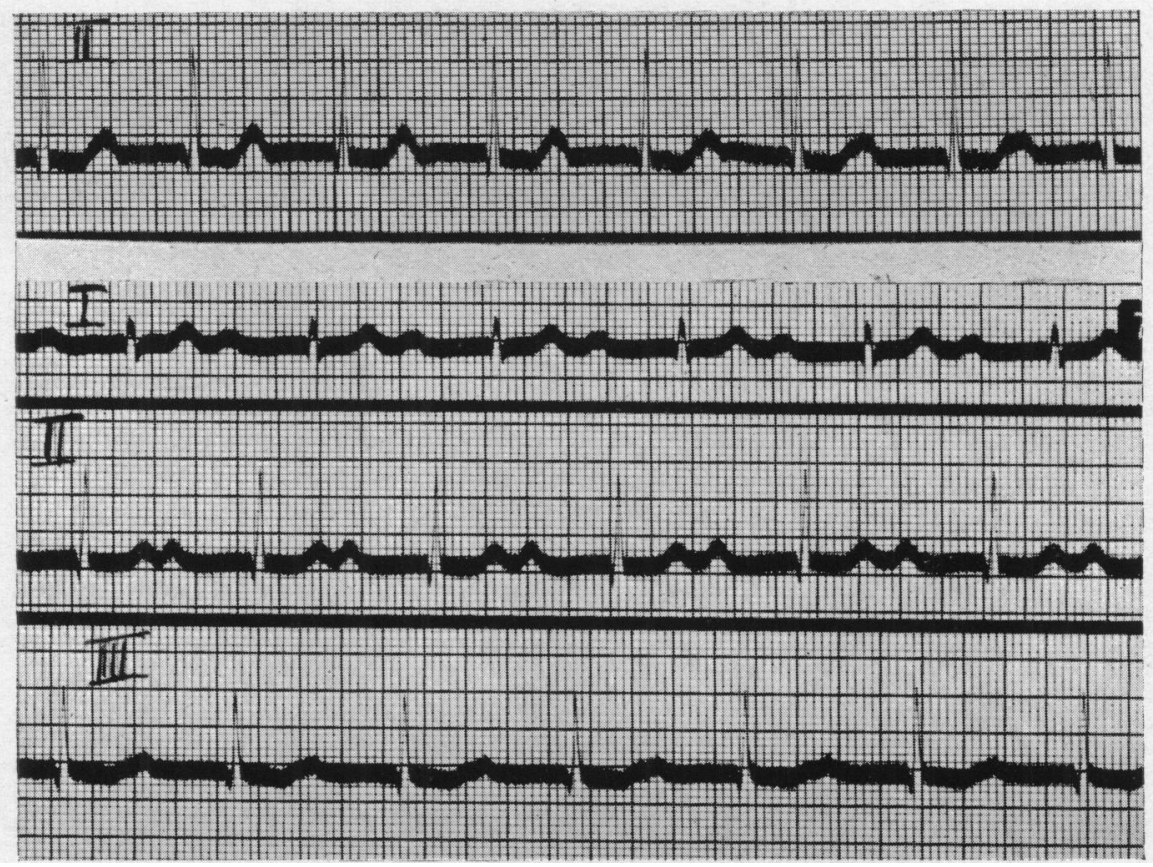

Fig. 4.-Electrocardiogram from the same patient as in Fig. 3 twenty-two years later, showing latent heart block with sinus tachycardia: the $P-R$ interval was about $0.44 \mathrm{sec}$. Sometimes, as in the upper record, the $\mathbf{P}$ wave is hidden in the preceding $\mathrm{T}$ wave. Case 7.

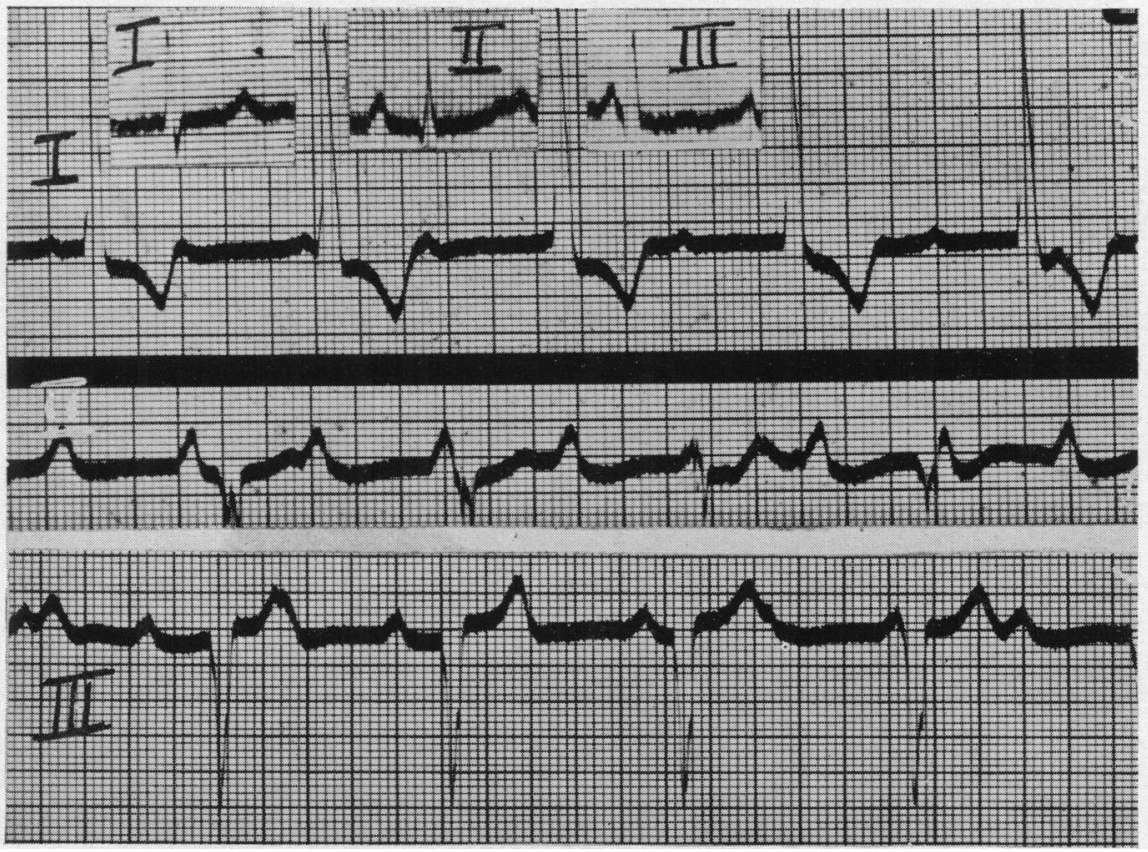

FIG. 5.-Inset above. Complete heart block with normal QRS complexes in 1933. Main figure. Electrocardiogram from the same patient fifteen years later (1948), showing left bundle-branch block, which has persisted. Complete heart block has been found throughout. Case 8 . 
to do less; he became a tobacconist, and though he still works a twelve-hour day he has felt better. $\mathrm{He}$ is somewhat breathless on strenuous exertion such as running for a bus, but he is overweight and has become bronchitic during the last five years, so that it is difficult to be certain that his symptoms are cardiac. His heart is the largest of any in this series (Fig. 6: c.t.r. 56\%) but has not increased during the last six years.

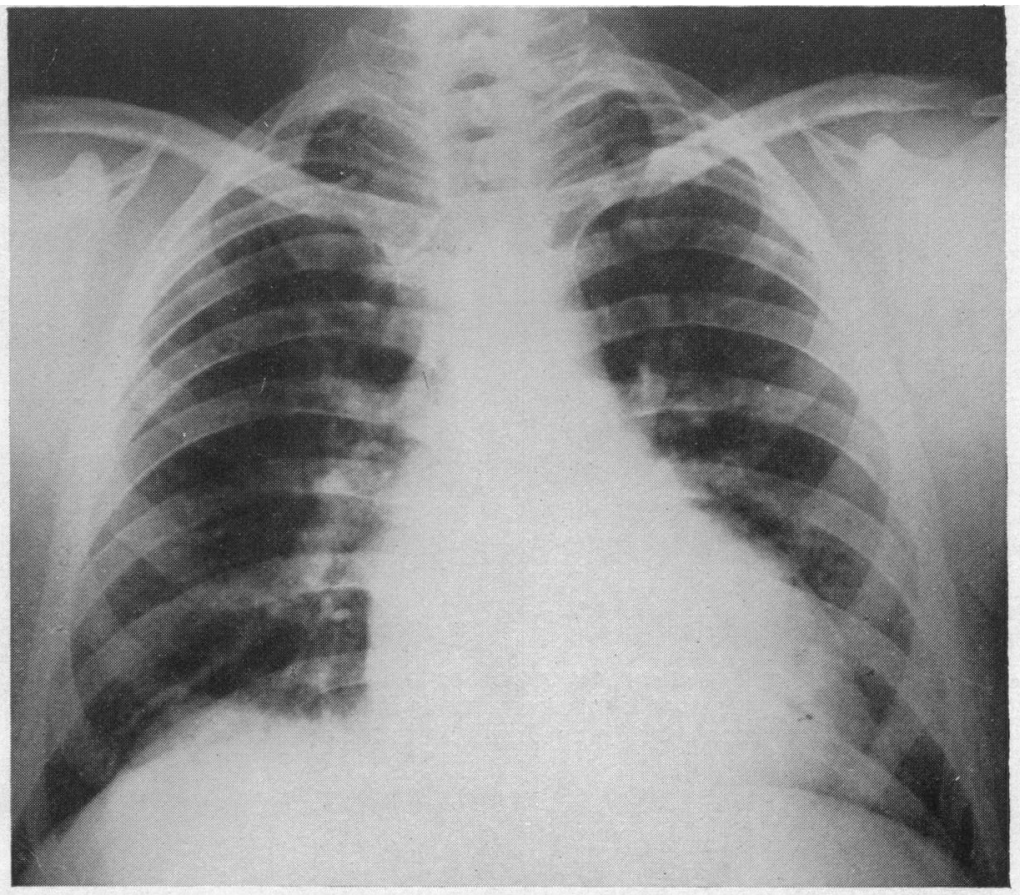

Fig. 6.-The only large heart in the series (c.t.r. $56 \%$ : m.t.d. $16 \cdot 2 / 29 \mathrm{~cm}$.). This patient had left bundle-branch block and probably aortic incompetence, which had not been present when he was younger. Case 8.

Case 9. This man, aged 49 when he died, was 29 when the diagnosis was first proved, so the heart block is less certainly congenital. When he was a child, however, his parents were told that his heart was not normal and when he was a student at Guy's Hospital he remembered having jaundice and being demonstrated as a case of bradycardia. When last reported, he was 36 years old and was leading a busy life as a dental surgeon. In 1947 he had a kidney removed for pyelonephritis.

When seen again in 1951 he had a dry skin and had been losing hair for two years; he had the appearance of myxœdema and a basal metabolic rate of -38 per cent. His heart rate (32-36) was at the lower end of his usual range, 32-42 a minute. With two grains of thyroid daily he lost all signs of myxœdema.

Earlier the same year he had some weakness of the left side and, later in the day, a speech defect from which he did not recover completely for three weeks. Since 1945 , there had been two other shorter attacks, both affecting his speech and his left side: he was left-handed. He was seen by Sir Charles Symonds also who thought he had thrombosis of the right internal carotid artery but a cerebral arteriogram failed to prove this. There was no special reason to suspect recurrent emboli. No change of heart rate was noted at the time of the attacks but a slower rate or cardiac standstill might have led to cerebral ischæmia and the symptoms might have taken this form rather than the usual Stokes-Adams attacks because of some local cerebral vascular abnormality. He made a good recovery and resumed much of his work but still had difficulty with a complex word or problem. 
Since this was written he has died. In November, 1954 , he had pyrexia up to $100^{\circ} \mathrm{F}$. and pain in the chest for a few days without hæmoptysis, but three weeks later he seemed as well as usual and no physical signs could be found. In March, 1955, the pain and pyrexia recurred, this time with hæmoptysis, and these continued. He was seen by Dr. Bodley Scott who has kindly informed us that there was no rise of venous pressure nor other signs of congestive failure, though he was somewhat orthopnœic. The heart was thought to be larger and the pulmonary second sound louder than they had been before, but the slow rate of 40 , the blood pressure, and the systolic murmur were unchanged. At the right base there was impairment of percussion, crepitations, and pleural friction. No peripheral venous thrombosis could be found and it was thought that the pulmonary infarction was more probably due to primary thrombosis, helped, perhaps, by the slow heart rate. $\mathrm{He}$ died two days later and throughout his final illness there was no episode to suggest any StokesAdams attacks or any change in his heart block. Unfortunately there was no necropsy and it is difficult to be certain what part his heart block may have played in his long and complex series of illnesses.

\section{The Findings in these Patients}

Physical Signs. The murmurs and other physical signs are described in the next section, when discussing the absence of any evidence for diagnosing a ventricular septal defect.

The Size of the Heart. This was normal in all the patients (Fig. 2) except Cases 5 and 8 (Fig. 6) and perhaps Case 9. Comparing all the X-ray films did not reveal any common feature, though most of the hearts were rather small, probably because of the patients' build, and the markings in the lung fields were rather prominent: they were, however, within normal limits and there was no expansile pulsation to support the presence of a left-to-right shunt.

TABLE I

Some Detalls of the Seven Patients with Congenital Heart Block

\begin{tabular}{|c|c|c|c|c|c|c|c|c|c|c|c|c|}
\hline \multirow{3}{*}{ 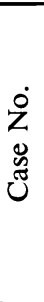 } & \multirow{3}{*}{ ๗్× } & \multirow{3}{*}{ 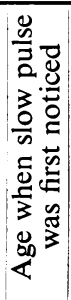 } & \multirow{3}{*}{ 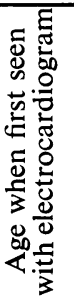 } & \multirow{3}{*}{ 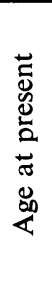 } & $\begin{array}{l}\text { Hea } \\
\text { (cardic }\end{array}$ & $\begin{array}{l}\text { size } \\
\text { oracic } \\
\text { io) }\end{array}$ & \multicolumn{4}{|c|}{ Heart rate at rest } & \multirow{2}{*}{\multicolumn{2}{|c|}{ Blood pressure }} \\
\hline & & & & & \multicolumn{2}{|c|}{ Percentage } & \multicolumn{2}{|c|}{1933} & \multicolumn{2}{|c|}{1954} & & \\
\hline & & & & & 1933 & 1954 & Atrial & Ventricular & Atrial & Ventricular & 1933 & 1954 \\
\hline $\begin{array}{l}2 \\
3 \\
4 \\
5 \\
7 \\
8 \\
9\end{array}$ & $\begin{array}{l}\mathrm{F} \\
\mathrm{M} \\
\mathrm{M} \\
\mathrm{F} \\
\mathrm{F} \\
\mathrm{M} \\
\mathrm{M}\end{array}$ & $\begin{array}{r}1 \\
2 \\
2 \\
2 \\
5 \\
13 \\
10\end{array}$ & $\begin{array}{l}12 \\
12 \\
12 \\
27 \\
20 \\
13 \\
29\end{array}$ & $\begin{array}{l}40 \\
35 \\
37 \\
56 \\
43 \\
38 \\
49\end{array}$ & $\begin{array}{l}56 \\
52 \\
+ \\
+ \\
50 \\
51 \\
53\end{array}$ & $\begin{array}{c}50 \\
46 \\
45 \\
++ \\
46 \\
56 \\
54\end{array}$ & $\begin{array}{r}112 \\
64 \\
136 \\
108 \\
96 \\
82 \\
86\end{array}$ & $\begin{array}{l}46-64 \\
43-52 \\
42-50 \\
44-50 \\
46-56 \\
44-56 \\
36-42\end{array}$ & $\begin{array}{c}83 \\
50-60 \\
100 \\
-* \\
86 \\
88\end{array}$ & $\begin{array}{c}48-70 \\
39-42 \\
42 \\
54 \\
* \\
46-56 \\
32-42\end{array}$ & $\begin{array}{l}160 / 80 \\
120 / 65 \\
120 / 50 \\
190 / 90 \\
150 / 90 \\
130 / 70 \\
125 / 80\end{array}$ & $\begin{array}{l}150 / 70 \\
105 / 65 \\
140 / 80 \\
260 / 120 \\
135 / 85 \\
160 / 90 \\
150 / 85\end{array}$ \\
\hline
\end{tabular}

The cardiothoracic ratios were generally about $45-50$ per cent (see Table I). Twenty years before they were though to be a little larger, about 52 per cent, but we can not be sure of the accuracy of the earlier figures which were taken from orthodiagrams while the later ones are from teleradiograms. It is, however, possible that the hearts were larger when the patients were younger and were leading more active lives that called for a larger stroke volume.

The Heart Rate. The heart beats much faster than is usual in acquired heart block, $40-50$ instead of 28-40 a minute (Campbell, 1944). In 1934 we thought that as the patients got older the rates might become slower and nearer to those in acquired heart block, but there is no evidence of this 
so far. In 1934 the rates were generally between 42 and 52 with an average of 48 a minute: in 1954 they were generally between 40 and 50 with an average of 47 a minute. In Cases 3 and 4 there was not much increase of rate with gentle exercise, but this point was not examined as fully as in 1933.

Brown (1950) says that the rate is generally between 36 and 92: Metianu and de Balsac (1954) put it between 40 and 80 and never less than 30 a minute. They add that the atrial rate is usually over 100 which is another point of difference from acquired heart block: it was often over 100 in our cases but was often slower, especially as the patients grew older.

The Blood Pressure. The blood pressure was generally within the usual range but the pulse pressure was wider to compensate for the slow heart rate. The average pulse pressure was 67 in 1933 and 75 in 1954, or 62 and 61 respectively if the patient with hypertension is excluded. In $1927-33$ the three older patients, then 27,21 , and 19 years old, had pressures of 190/90, 150/90, and 160/80: the first, now aged 56, has a pressure of $260 / 120$ and as the diastolic has risen this probably indicates essential hypertension, but the other two have not maintained the high pressures as they have grown older and the readings are now 135/85 and 150/70.

The Electrocardiogram. This was normal apart from the heart block (Fig. 1), except in Case 8 with left bundle-branch block (Fig. 5) and Cases 3 and 4 with some tendency to left ventricular preponderance ( $\mathrm{S}$ in V1 being 12 and $13 \mathrm{~mm}$. and $\mathrm{R}$ in V6 being 14 and $9 \mathrm{~mm}$. respectively); in Case 9 there was rather low voltage in the standard but not in the unipolar leads.

\section{The Association with Ventricular Septal Defects}

In 1934 we thought that the systolic murmur heard in most of these patients indicated a ventricular septal defect, as it was a common view that these two congenital lesions often occurred together. This point has been re-examined more critically now that the nature of the congenital heart lesions can be diagnosed more accurately. All but one of the patients had a systolic murmur but generally it seemed to be functional or cardio-respiratory rather than organic. In 1932 only one was thought to have a systolic thrill and in 1954 a thrill could not be felt in any of them. In most of them the lung markings were dense rather than light but all were within normal limits, so there was no evidence of any left-to-right shunt.

In Case 2, a systolic murmur of moderate intensity was heard in the third and fourth left interspaces but no thrill was felt, and on radioscopy the pulsation and density of the lung fields were within the upper limits of normal and there was no enlargement of either ventricle, so it is unlikely that there was any shunt through a septal defect. In Case 3 the systolic murmur was recorded as rather harsh when he was a boy, but twenty years later no murmur could be heard and the heart was small normal. In Case 4 a soft systolic murmur was heard best inside the apex but it was sharply localized and changed with respiration; no thrill was felt and the heart was of normal size and shape, so the murmur can hardly be organic.

In Case 5 there was in 1927 a systolic murmur heard best towards the apex but no thrill: in 1955 her doctor did not think the murmur significant; the heart was larger but this was probably due to essential hypertension. In Case 7 the systolic murmur was soft and could be dismissed as functional, as there was no thrill, no enlargement of the heart, and no abnormal pulsation on radioscopy. In Case 8 there was an additional lesion: there was no thrill but a moderate systolic murmur in the third and fourth left spaces from the midline to near the apex, a diastolic murmur that was easily heard above this, and a normal second sound. Probably he had aortic regurgitation though the murmur was heard rather low and on the left, the pulse pressure was no wider than in other cases, and on radioscopy both ventricles seemed enlarged. A large ventricular septal defect was excluded by the normal appearance of the lung fields on radioscopy. In Case 9 the systolic murmur was loudest and most constant near the apex though it varied with deep respiration, no thrill was felt, the heart was slightly enlarged but had not changed during eight years, and the lung fields were normal, so even a small ventricular septal defect is unlikely.

There is, therefore, no patient in whom a ventricular septal defect or any other congenital lesion 
can be diagnosed with confidence. Case 8 has aortic incompetence possibly from atherosclerosis of bicuspid aortic valves and Cases 2 and 9 might have small ventricular septal defects of the maladie de Roger type but this is unlikely in the absence of a thrill. Case 3 has no murmur at all and the other three have systolic murmurs that are probably functional.

\section{The Incidence of Congenital Heart Block}

Although these patients were all seen within a few years and led us to believe that congenital heart block was more common than was generally thought, subsequent experience has not supported this view and we have seen few cases since. Among the many infants at Guy's and the Evelina Hospitals in the last thirty years we can remember only one with heart block being referred to the Cardiac Department. The heart block was sometimes $3: 1$ and sometimes $2: 1$ and he was thought to have congenital fibrocystic disease of the pancreas (Trounce and Potter, 1952).

Among the many patients with congenital heart disease that we have seen since 1947, complete or partial heart block has not been common, but has been found in 8 out of about 1800 cases. Even latent heart block is not very common, though it has been noted in several severe cases of simple pulmonary stenosis and of atrial septal defect and in some others.

Before discussing these we are reporting two other possible examples of the type seen in Group I, but the evidence is much less complete than in our earlier cases.

Case 10. A woman, aged 32 years, complained of occasional palpitation, of giddiness on change of posture, and some three years previously of some fainting attacks. There was no history of rheumatic fever or of diphtheria. Her heart rate was found to be 50-60 and on exercise rose to 90 , but there was complete heart block, with an atrial rate of 100 a minute. The heart was not enlarged and there was no thrill, but a systolic murmur was heard at the apex. She was seen at intervals for two years during which time there was no change, but then she emigrated to Australia.

Case 11. A man, aged 31, who was leading an active life and playing football, was seen because of his slow heart rate. He had complete heart block with a ventricular rate of 40 , but no other abnormality could be found. When in hospital eighteen years before with scarlet fever, his pulse rate had been charted between 70 and 100 a minute. Six years later he was much the same except that his blood pressure had risen from $150 / 85$ to $180 / 100$. He still showed complete heart block with a ventricular rate of 41 and an atrial rate of 122. The main reason against accepting his block as congenital is that he was passed for military service without comment, but Case 3 served in the R.A.F. and was passed for flying duties.

\section{Patients with Heart Block and other Congenital Heart Abnormalities}

(Group II)

The other congenital abnormalities associated with heart block in these eight cases were not of any one type and there was not the usual predominence of uncomplicated Fallot's tetralogy among the cyanotic cases. Three had Fallot's tetralogy, but one with situs inversus and one in its acyanotic form. One had Eisenmenger's complex, one was thought to have tricuspid atresia, and one transposition of the aorta and pulmonary.trunk. The remaining two were acyanotic: one was a classical example of atrial septal defect and the other was thought at first to have this but the diagnosis was uncertain.

In Group I the heart block was nearly always complete, but in this group who had other congenital defects it was more variable. In 5 of the 8 it was so far as we know always complete. In the sixth it was sometimes $2: 1$ and sometimes complete (Case 14), and in the seventh it was sometimes $2: 1$ and sometimes latent with a P-R interval of $0.28 \mathrm{sec}$., and later complete (Case 15). In the last we have no evidence that it was ever complete, and there was partial block with Wenkebach's periods (Case 18). We do not know that the heart block dated from birth in these cases and three of them were 30,35 , and 42 years of age when first seen, so acquired block can not be excluded but seems unlikely.

The rate when the block was complete was, in general, faster than in our patients of Group I and much faster than in acquired block, abour 52 to 70 a minute, but it was only 33 in Case 12, a woman aged 42. This relatively rapid rate made it all the more difficult to say how long the block had been 
present and generally it had not been recognized before we saw them. Some details about these eight patients are given in Table II and short case notes follow.

Case 12. A woman, aged 42 , had been cyanosed from infancy. She had been fairly well till she was twenty and then became progressively more disabled, and when she was seen she had congestive failure. There was complete heart block with a ventricular rate of 33 a minute, and she was thought to have tricuspid atresia, but no investigations were carried out. She died two years later and there was no necropsy.

Case 13. A girl, aged 14, was thought to have Fallot's tetralogy with dextrocardia and complete situs inversus. As far as is known, her block was always complete with the ventricular rate between 50 and 60 . She has got on well for four years.

Case 14. A boy, aged 12, had doubtful cyanosis and had become rather more breathless in the last year. Catheterization showed a moderate pulmonary stenosis as well as a left-to-right shunt through a ventricular septal defect: the arterial oxygen saturation was 95 per cent, so that he belongs to the group of acyanotic Fallot's tetralogy. He had complete heart block at a rate of 50-64 a minute. Later, in hospital the block was sometimes complete and sometimes $2: 1$ and his pulse rate was generally between 48 and 70 a minute.

Case 15. A woman, aged 35 , had always been disabled but not seriously before she was 28 , when she became worse till she could walk only a quarter of a mile. She was thought to have Fallot's tetralogy. She showed 2:1 heart block, but we do not know when this had developed. A year later there was latent heart block with a P-R interval of $0.28 \mathrm{sec}$. Six years later she has developed congestive failure and when she was seen there was complete heart block with a ventricular rate of 48 ; this was about the usual rate but it had been about 64 for three weeks some months previously.

Case 16. A woman, aged 30, was always breathless and began to notice cyanosis when she was nine; it had increased since though it was not severe. She had been finding her work as a dressmaker more difficult the last two years. The signs suggested Eisenmenger's complex with pulmonary regurgitation, and catheterization confirmed the high right ventricular pressure, though the pulmonary artery was not entered. There was complete A-V dissociation with the atrial rate 70-84 and the ventricular rate $64-73$ a minute (Fig. 7).

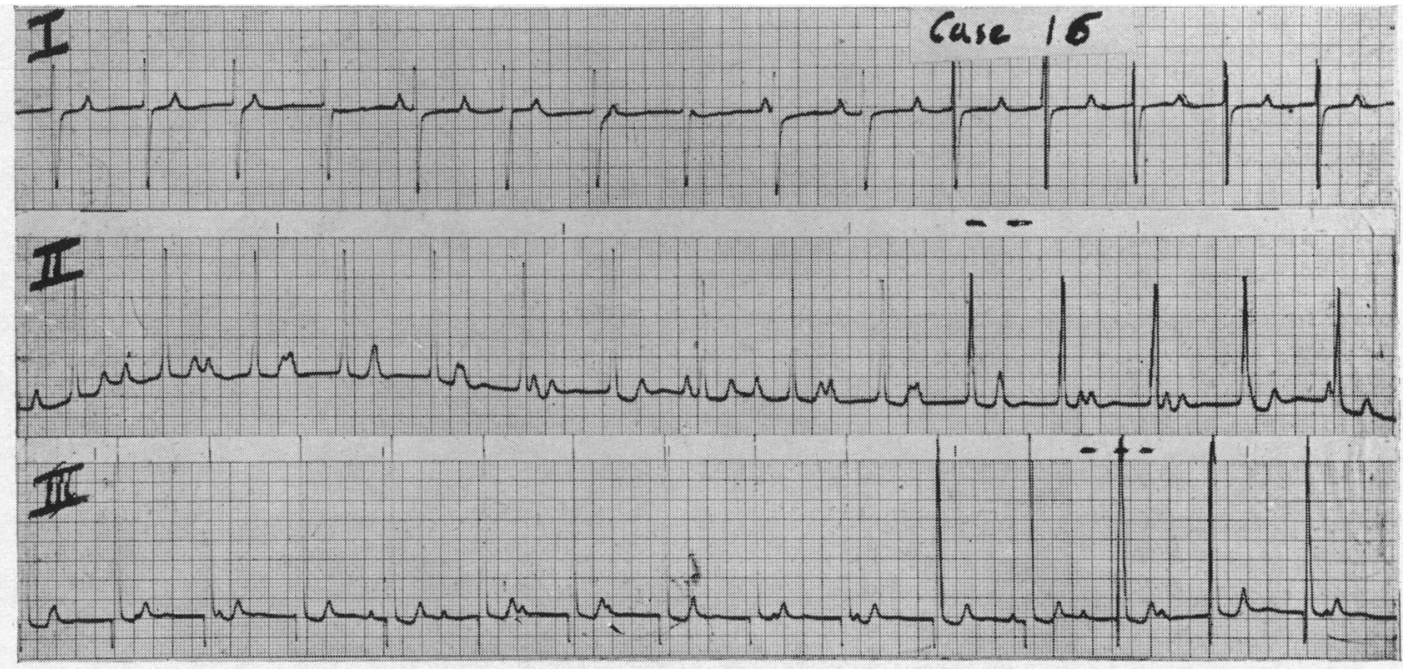

FIG. 7.-Complete heart block with a rapid ventricular rate of 64 a minute (atrial, 70). From a patient with Eisenmenger's complex. Case 16.

Case 17. A boy, aged 12, had always been cyanosed and moderately disabled though he could walk a mile slowly. The blood flow to his lungs was increased, and he was thought to have partial transposition of the aorta and pulmonary trunk. His pulse rate had always been slow and this was due to complete heart block with a ventricular rate of 60 a minute.

Case 18. A boy, aged 14, was thought to have an atrial septal defect. He had few symptoms and no comment had been made on his heart rate, but when he attended hospital the rhythm was irregular because 
of partial heart block with Wenkebach's periods and dropped beats, the P-R interval lengthening from 0.26 to $0.33 \mathrm{sec}$. The condition was the same a year later (Fig. 8).

Case 19. A girl, aged 6, was not much disabled but was found to have lungs that looked pleonæmic and a large heart (c.t.r. $66 \%$ in $1950,58 \%$ in 1955). During five years observation her heart rate was slow, due to complete heart block with the ventricular rate about 45 to 60 a minute. She was thought to have an atrial septal defect, but catheterization did not reveal any abnormality. We have, however, left her in this group because the pulmonary changes were too striking and the heart too large to accept it as normal apart from the heart block.

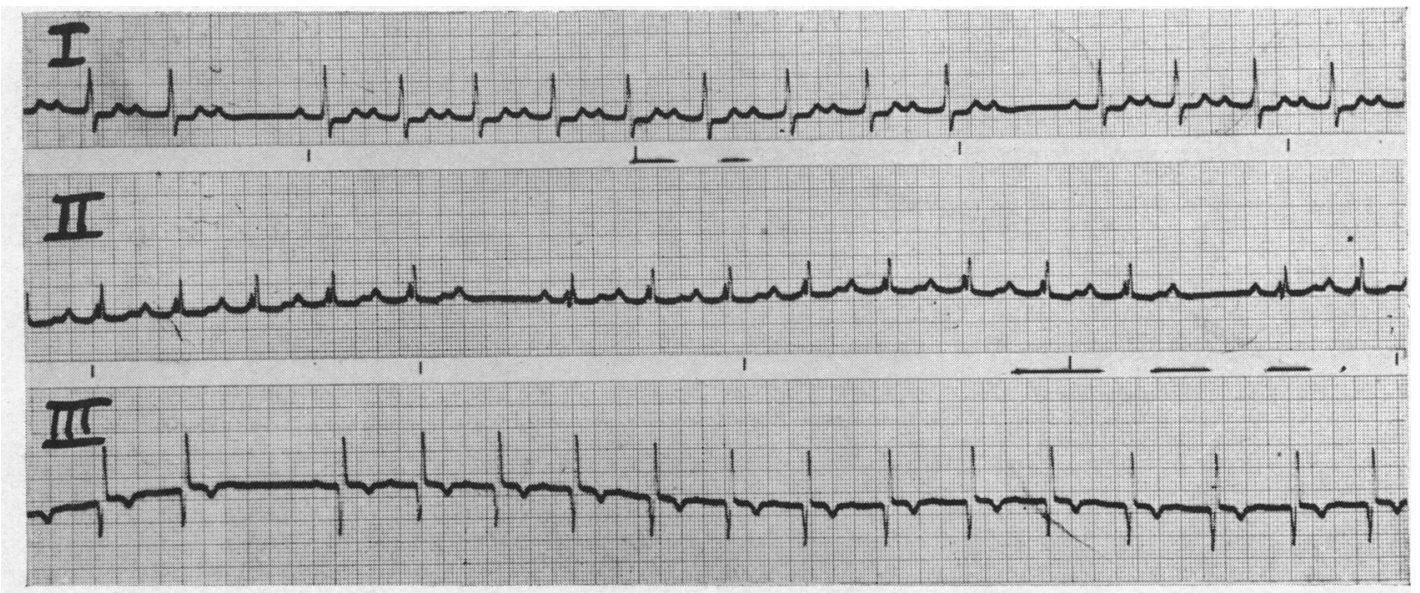

FIG. 8.-Partial heart block with Wenkebach's periods and dropped beats from a patient who showed this at both visits at a year's interval. He had an atrial septal defect. Case 18.

TABLE II

Some Details of Eight Patients with Congenital Heart Disease and Heart Block

\begin{tabular}{|c|c|c|c|c|}
\hline $\begin{array}{l}\text { Case } \\
\text { No. }\end{array}$ & $\begin{array}{l}\text { Age } \\
\text { and } \\
\text { sex }\end{array}$ & Diagnosis & $\begin{array}{c}\text { Heart } \\
\text { size } \\
\text { (cardio- } \\
\text { thoracic } \\
\text { ratio \%) }\end{array}$ & Degree of heart block \\
\hline 12 & F42 & Uncertain, perhaps tricuspid atresia & 55 & Generally C.H.B. (A, 96: V, 33) \\
\hline (CBIJ) & F14 & Fallot's tetralogy with situs inversus & 47 & C.H.B. (A, 78-100; V, 50-60) \\
\hline 14 & M12 & Acyanotic Fallot's tetralogy & 52 & C.H.B. (A, 110; V, 48-70) and $2: 1$ \\
\hline $\begin{array}{l}15 \\
(0127)\end{array}$ & F35 & Fallot's tetralogy & $61^{*}$ & $\begin{array}{l}2 \cdot 1 \text { block }(P-R, 0.24 \text { sec.) and latent } \\
\text { block (P-R, } 0.28 \text { sec.), and later }\end{array}$ \\
\hline $\begin{array}{c}16 \\
(\mathbf{P 1 7 3})\end{array}$ & F30 & Eisenmenger's complex & 57 & $\begin{array}{l}\text { C.H.H.B. (A, 70-84; V, 64-73) } \\
\text { C.H. }\end{array}$ \\
\hline $\begin{array}{l}17 \\
(1312)\end{array}$ & M12 & $\begin{array}{l}\text { Transposition of aorta and pulmonary } \\
\text { trunk }\end{array}$ & 56 & C.H.B. $(A, 85 ; \mathrm{V}, 60)$ \\
\hline $\begin{array}{l}18 \\
(1035)\end{array}$ & M14 & Atrial septal defect & 62 & Partial H.B. with Wenkebach's periods \\
\hline $\begin{array}{c}19 \\
\text { (P339) }\end{array}$ & F6 & ?Atrial septal defect & $66-58$ & C.H.B. (A, 75-90; V, 45-60) \\
\hline
\end{tabular}

* The kyphoscoliosis was so severe that this was very uncertain. 


\section{Discussion}

The association of congenital heart block with a ventricular septal defect will be discussed first, and then the variability in degree and form of the block, and the prognosis of patients suffering from this condition.

The Presence of a Ventricular Septal Defect or other Abnormalities. It was assumed at one time that an underlying structural defect, usually a patency in the ventricular septum, interrupted normal conduction; White (1951) for example wrote "Congenital interventricular septal defects are the rule in the very rare cases of congenital heart block " and Friedberg (1950) thought it was almost always associated with such a defect. Taussig (1947) thought that it rarely occurred without some other congenital lesion but that this was a defect of the atrial septum as often as of the ventricular septum. The evidence supporting these views does not seem strong enough to merit such emphasis. Yater et al. (1933) for example found that signs suggestive of a ventricular septal defect were present in only 27 of the 44 reported cases of congenital heart block, and Brown (1950) found this in 51 of 77 cases but in only 5 of 12 cases with necropsy: in view of the changed views about the clinical diagnosis of ventricular septal defect the earlier figures are not reliable.

Certainly a number of cases have, at necropsy, shown a ventricular septal defect (Yater $e$ t al., 1934; Towers and Bremer, 1947; and Clark and White, 1952). Among the eleven necropsies quoted by Wallgren and Winblad (1951) the following abnormalities were observed; a defect of the ventricular septum in six cases, amounting to cor triloculare in three, with or without other associated defects, partial transposition of the heart and viscera in one, and patency of the inter-atrial septum in three. One of these last three and one other who had no associated abnormality had a fibrous interruption of the bundle of His. These, however, have been a selected group in whom a relatively early death was probably associated with an unusually high incidence of serious structural defects. Of our eight patients with congenital heart disease and with heart block (Group II), each of the six cyanotic patients had a ventricular septal defect among the other abnormalities but the two acyanotic patients had not.

The presence of a ventricular septal defect is no reason for expecting to find heart block and this is true even when there is a single ventricle and no ventricular septum (Campbell et al., 1953). Monckeberg (1924) showed that in nearly all cases of ventricular septal defect, even when the septum is completely absent, the bundle is conserved though its position may be abnormal. Furthermore there have been many reported cases of heart block where the diagnosis of ventricular septal defect has not been made and others where it may be questioned. The finding of a thrill is unusual, and even when a præcordial systolic murmur has been recorded it is by no means certain that it indicates the presence of such a defect. Fisch (1948) for example has suggested that it might be due to an increased stroke volume secondary to the bradycardia; while Sprague and White (1927) did not think that the systolic murmur in four of their series of patients with complete block justified the diagnosis of the block as congenital and described it simply as idiopathic. Leach (1930) thought there was no good evidence that the lesion was usually a defect in the ventricular septum.

Finally, it has been suggested that the block is due not so much to a hole in the septum as to the presence of fibrous tissue interrupting or pressing on the bundle of His; such abnormalities have been found at necropsy (Lampard, 1928; Yater et al., 1933; and Wallgren and Winblad, 1937). Brown (1950) points out that the most vulnerable part of the A-V bundle is where it passes in the posterior part of the endocardial canal between the endocardial cushions, and that abnormal ingrowth of the fibrous tissue of the annulus fibrosus might interrupt its course here.

Apart from the heart block, only Case 8 among our seven patients of Group I had evidence of any structural fault. Reasons have been given for thinking that he had developed aortic incompetence sometime after he was 20, possibly from pathological changes on congenital bicuspid aortic valves. Towers and Bremer (1947) have reported a case of supposed congenital aortic incompetence with complete heart block. The other six of our seven patients showed no evidence of ventricular septal defect or other congenital abnormality. One of the criteria of Yater for 
accepting heart block as congenital, viz. other signs of congenital heart disease, should therefore be omitted, and all that is needed is recognition of the slow pulse at an early age before there is any history of diphtheria or of rheumatic fever.

The Association with Bundle-Branch Block. The occurrence of bundle-branch block with acquired heart block is not uncommon (Kay, 1948): Campbell (1944) for example found it in 19 out of 64 patients. The complication suggests extensive involvement of the conducting system, usually as a result of coronary disease, and carries a poor prognosis. Thus Katz (1941) maintained that the average expectation of life was " seldom longer than a year or two." In patients with congenital heart block, however, a bundle-branch block pattern appears to be uncommon, and Kay found it in only one out of twenty patients. Here, as in our Case 8, it was of the left bundle-branch type.

Variations in the Type and Degree of Heart Block. These changes seem to be more common in patients with acquired than with congenital block. Thus Ellis (1932) found that in his series of 43 patients the condition was acquired in the 3 who had intermittent complete block, while his 9 congenital cases showed no intermissions. Similarly all 12 cases of intermittent block of Butler and Levine (1930) were examples of the acquired condition. Nevertheless several congenital cases with altering block have been recorded. The patient of Waldman (1945) showed at different times prolongation of the P-R interval and complete A-V dissociation; the patient of Faessler (1939) showed sinus rhythm, A-V nodal rhythm, and complete block; and other examples are given in Table II.

Waldman suggested that there were two ways in which these variations could occur. An incomplete interruption of the conducting fibres could be rendered temporarily complete by increasing mechanical tension applied to the bundle; and here he cited the patient of Smith (1921) in whom normal sinus rhythm could be restored during forced expiration when the heart lay in a more horizontal position. Or a disturbance of the blood supply to the conducting system might produce a similar effect; and here he quoted Faessler's (1939) patient who was found at necropsy to have gross atheroma of the artery to the A-V node, besides other abnormalities. Whatever the cause of these variations, it is easier to understand why a patient with incomplete block should subsequently develop complete block (Clark and White, 1952) than why the reverse should happen, as it did in our Case 7.

Prognosis. Opinions on the prognosis of congenital complete heart block have varied. Yater et al. (1933) stated that " it should be considered serious in all cases since a major defect is probably always present" and Leech (1930) also thought the outlook unfavourable. Most workers (Taussig, 1947; White, 1951) take a more optimistic view, however, and a number of patients are known to have had the condition for long periods, 56 years (our Case 5), 40 years (our Case 2), 35 years (Benjamin and White, 1952), over 30 years (Smith, 1933), 28 years (Harris, 1929), 26 years (Clark and White, 1952), and 24 years (Butler and Levine, 1930; Ellis, 1932). The prognosis must depend on whether " a major developmental defect" is in fact present in most patients, and this question has been discussed. We think that the structural abnormality, when present is not so much a cause of the block as a parallel manifestation of deranged development. Langendorf and Pick (1954) also suggest that the responsible defect is in the bundle of His itself rather than a mechanical interruption of a normal bundle of His by the septal defect or other structural abnormality.

It should not be thought that the heart block itself is never of importance, for sudden death, due presumably to acute disturbances of cardiac rhythm, has been reported in these patients (Aylward, 1928; Aitken, 1932; Ellis, 1932; Clark and White, 1952). In general, however, we agree with Brown (1950) and in our opinion the prognosis is that of the associated lesion, if any, and the heart block itself is generally unimportant.

\section{SUMMARY AND CONCLUSIONS}

Seven patients with congenital complete block, who have been reported previously, have now been followed for twenty-five years and their progress and present condition are described. One 
has died from an obscure cardiovascular condition, but the others are all doing well. When they were last reported the block had so far as was known been complete all the time but one has since developed sinus rhythm with latent heart block.

Only one has a large heart and evidence of an additional lesion, probably aortic incompetence. All the others have systolic murmurs that are thought to be functional or cardio-respiratory. None has a palpable systolic thrill or any good evidence of a ventricular septal defect, though this was suspected originally because of the systolic murmur.

Although the patients are growing older the heart rate is still faster than in acquired heart block, 40 to 50 instead of 28 to 40 a minute. The pulse pressure is generally somewhat widened, about $60 \mathrm{~mm}$., but there is no tendency for the blood pressure to rise as the patients get older. Apart from the block the electrocardiogram is generally normal.

We are reporting also eight new patients with heart block and manifest congenital heart diseasethree with Fallot's tetralogy (one of these with dextrocardia), one with Eisenmenger's complex, one with transposition of the main arteries, one perhaps with tricuspid atresia, and two with atrial septal defect. The first five of these have, of course, a ventricular septal defect as well as other congenital lesions. Here the heart block was less often complete and $2: 1$ block or latent block with dropped beats were sometimes seen. When the block was complete the ventricular rate was even faster than in the first group, generally between 50 and 70 a minute.

When there is an added structural abnormality, this is not as a rule the direct cause of the block, so much as a parallel disturbance of development. Sometimes the block is due to a fibrous interruption of the bundle of His.

In general, the prognosis is that of the associated lesion and it is not greatly affected by the presence of the heart block.

\section{REFERENCES}

Aitken, J. K. (1932). Lancet, 2, 1375.

Aylward, R. D. (1928). Brit. med. J., 1, 943.

Benjamin, J. E., and White, P. D. (1952), J. Amer. med. Ass., 149, 1549.

Brown, J. W. (1950). Congenital Heart Disease. 2nd ed. Staples Press, London.

Butler, S., and Levine, S. A. (1930). Amer. Heart J., 5, 592.

Campbell, M. (1943). Brit. Heart J., 5, 15.

(1944). Brit. Heart J., 6, 69.

, Reynolds, G., and Trounce, J. R. (1953). Guy's Hosp. Rep., 102, 99.

, and Suzman, S. (1934). Amer. Heart J., 9, 304.

Clark, R. J., and White, P. D. (1952). Circulation, 5, 725.

Ellis, L. E. (1932). Amer. J. med. Sci., 183, 225.

Faessler, B. (1939). Ann. Padiat., 153, 327.

Fisch, C. (1948). New Eng. J. Med., 238, 589.

Friedberg, C. K. (1950). Diseases of the Heart. W. B. Saunders, Philadelphia and London.

Harris, K. E. (1929). Heart, 14, 289.

Katz, L. N. (1941). Electrocardiography. Lea and Febiger, Philadelphia.

Kay, H. B. (1948). Brit. Heart J., 10, 177.

Lampard, M. E. (1928). Arch. Dis. Childh., 3, 212.

Langendorf, R., and Pick, A. (1954). Pediat. Clin. N. Amer., 1, 215.

Leech, C. B. (1930). Amer. J. Dis. Child., 39, 131.

Metianu, C., and de Balsac, R. H. (1954). Traité des Cardiopathies congenitales. Sous la direction de E. Donzelot et F. D'Allaines. Masson et Cie, Paris.

Monckeberg, J. C. (1924). Henke u. Lubarsch. Handb. d. spez. Anat. u. Hist., $2,122$.

Potter, C. T., and Trounce, D. Q. (1952). Brit. Heart J., 14, 291.

Smith, H. L. (1933). Amer. Heart J., 8, 719.

Smith, S. C. (1921). J. Amer. med. Ass., 76, 17.

Sprague, H. B., and White, P. D. (1927). Med. Clin. N. Amer., 10, 1235.

Taussig, H. B. (1947). Congenital Malformations of the Heart. Commonwealth Fund, New York.

Towers, J. R. H., and Bremer, C. (1947). Brit. med. J., 2, 906.

Waldman, S. (1945). Amer. Heart J., 30, 92.

Wallgren, A., and Winblad, S. (1937). Acta padiat. Stockh., 20, 175.

White, P. D. (1951). Heart Disease. Macmillan, New York.

Yater, W. M., Leanan, W. G., and Cornell, V. H. (1934). J. Amer. med. Ass., 102, 1660.

—, Lyon, J. H., and McNabb, P. E. (1933). J. Amer. med. Ass., 100, 1831. 